\title{
Velilerin Okul Öncesi Eğitim Hakkında Görüşlerinin İncelenmesi
}

\author{
Ahmet Sami KONCA \\ Kayseri Erciyes Üniversitesi Eğitim Fakültesi \\ samikonca@erciyes.edu.tr \\ ORCID ID: 0000-0002-6423-6608
}

\begin{tabular}{lrr} 
Araştırma Makalesi & DOI: $10.31592 /$ aeusbed.804853 \\
\hline Geliş Tarihi: 03.10 .2020 & Revize Tarihi: 06.11.2020 & Kabul Tarihi: 13.11 .2020
\end{tabular}

\section{Atıf Bilgisi}

Konca, A. S. (2020). Velilerin okul öncesi eğitim hakkında görüşlerinin incelenmesi. Ahi Evran Üniversitesi Sosyal Bilimler Enstitüsü Dergisi, 6(3), 892-902.

\section{$\ddot{\mathbf{O Z}}$}

\begin{abstract}
$\mathrm{Bu}$ araştırmada çocuklarını okul öncesi eğitim kurumlarına gönderen ebeveynlerin okul öncesi eğitim hakkında düşünceleri araştırılmıştır. Bu doğrultuda, velilere göre okul öncesi eğitimin ne olduğu, velilerin çocuklarını okul öncesi eğitim kurumlarına gönderme nedenleri, okul öncesi eğitimde yapılan uygulamalardan memnuniyetleri ile velilerin okul öncesi eğitime yönelik istek ve önerileri incelenmiştir. Araştırmaya 7'si kadın 4'ü erkek 11 veli katılmıştır. Katılımcılarla 15 sorudan oluşan yarı yapılandırılmış görüşmeler yapılmış, veriler ses kayıt cihazı ile kaydedilmiştir. Elde edilen veriler transkript edilerek kodlama yoluyla analiz edilmiştir. Araştırmadan elde edilen sonuçlara göre veliler okul öncesi eğitimi tanımlarken gelişim, beceri, uyum ve hazır bulunuşluk kavramlarına yönelik ifadeler kullanmaktadırlar. Velilerin çocuklarını okul öncesi eğitim kurumlarına gönderme nedenlerine bakıldığında ise beceri kazanımı, sosyal hayatı destekleme, gelişimi destekleme ve ilkokula hazırlık amaçları ön plana çıkmıştır. Veliler sinematiyatro gibi faaliyetler, akran etkileşimi, sorumluluk üzerine yapılan aktivitelerden memnuniyet duyarken maddi külfet gerektiren aktiviteler ile kültürel farkl1lıklar içeren medya içeriklerini okul öncesi eğitime yönelik olumsuz görüş olarak bildirmişlerdir. Velilerin istekleri incelendiğinde ise veliler öğretmenden, eğitim ortamından, maddi konularda destekten ve diğer öğrenci-velilerden farklı istek ve önerilerde bulundukları görülmüştür.
\end{abstract}

Anahtar Kelimeler: Okul öncesi eğitim, ebeveyn, veli, görüş.

\section{Parents Views About Early Childhood Education}

\begin{abstract}
This study aimed to investigate parents' views regarding early childhood education. To this aim, the concept of early childhood education according to the parents, parents' reasons for sending their children to early childhood institutions, and parents' satisfactory and demands from early childhood education were investigated in this study. 7 female and 4 male parents included in the study. Semi structured interviews which consisted of 15 questions were implemented to the participants and the interviews were audio recorded. The data transcribed and analyzed through coding process. Results of the study showed that parents used development, skill, accommodation and readiness to school terms to define early childhood education. Parents' reasons to send their children to early childhood education were acquiring skills, supportidemang social life, supporting development of children, and school readiness. While parents implied cinema-theatre activities, peer interaction, and the activities including responsibility of children as pros of early childhood education, they mentioned financial burden of the activities and the content of the activities which was not in parallel with culture of the children as cons of early childhood education. Besides, parents had different demands from teachers, schools, financial supports and other students and families.
\end{abstract}

Keywords: Early childhood education, parents, views.

\section{Giriş}

Okul öncesi eğitim; çocuğun doğduğu günden başlayarak ilköğretime kadar geçen yılları kapsayan, çocuğun gelişim düzeyine ve bireysel özelliklerine uygun, psiko-motor, bedensel, zihinsel, sosyal-duygusal ve dil gelişimlerini desteklemeyi hedefleyen, onlara zengin uyarıcılı çevre olanağı sağlayan ve onları ilköğretime hazırlayan, sistemli ve bilinçli bir eğitim süreci olarak tanımlanmaktadır (Kuru Turaşlı, 2010). Bu bağlamda ülkemizde sürdürülen okul öncesi eğitimin genel amaçları; şartları elverişsiz çevrelerden ve ailelerden gelen çocuklar için ortak bir yetişme ortamı yaratmak, çocukların beden, zihin ve duygu gelişmesini ve iyi alışkanlar kazanmasını sağlamak, onları 
ilköğretime hazırlamak, çocukların Türkçeyi düzgün ve güzel konuşmalarını sağlamaktır (Millî Eğitim Bakanlığ1 [MEB], 2013).

Türkiye'de okul öncesi eğitim kavramı 0-6 yaş aralığını belirtmektedir (Toran, 2012). 20182019 döneminde hizmet veren toplam 31813 okul öncesi kurumu vardır ve bu kurumlardaki toplam çocuk sayısı 1564 813'tür (TÜİK, 2020). 93302 öğretmenin görev yaptığı bu dönemde net okullaşma oranı ise \%39,1 olarak belirlenmiştir. $\mathrm{Bu}$ oran, ülkemizde bu zamana kadar ulaşılan en yüksekokullaşma oranı olmuştur. Kalkınma plânlarında yer alan okul öncesi eğitimde okullaşma oranının \%100'e ulaştırılması amacıyla devlet bünyesinde yer alan okul öncesi eğitim kurumlarının sayısı hızla artmakta, bu artışla birlikte bazı sorular ve sorunlar da gündeme gelmektedir.

Okul öncesi eğitimin paydaşlarının en önemlilerinin başında aile gelmektedir. Bronfenbronner'in (1989) ekolojik kuramına göre aile mikrosistemin içerisinde bulunarak çocuğun etkilediği ve onlardan etkilendiği en yakınındaki kişileri oluşturmaktadır. Ayrıca, Vygotsky'nin (1978) sosyo kültürel gelişim kuramına göre çocuklarda öğrenme sosyal etkileşimler aracıllğı ile gerçekleşir. Çocuğun sosyal ve kültürel özellikleri öğrendiği temel ortam olan aile çocuğun gelişimi ve öğrenmesinde önemli bir rol oynamaktadır. Ailenin çocuğun gelişimi ve eğitimindeki önemi doğrultusunda aile-okul etkileşimi, iletişimi ve iş birliği de önem kazanmaktadır. Bu bağlamda, birbirleriyle ortak özellikleri ve deneyimleri olan ailelerin okul öncesi eğitim hakkında düşünceleri, beklentileri ve yaşadıkları sorunların araştırılıp ortaya konması elzemdir.

\section{Okul Öncesi Eğitim ve Veliler}

"Bir çocuk anaokulunun odasının eşiğinden geçtiği zaman, bir ebeveyn onun orda olduğunu bilir fakat ona dokunamaz, onu korkudan acıdan başarısızlıktan öfkeden veya tehlikeden koruyamaz, onu rahat ettiremez, oyuncağını ve başarılarını paylaşamaz. Bir anne hayali olarak sınıfta ne olduğunu düşünebilir fakat sınıfin tamamını göremez. Anaokulu sinıfindaki akranlar ebeveynin endişesini hem yatıştırır-hem de artırır" (McClelland, 1995, s.1).

Çocukların okul öncesi eğitime dâhil olmalarıyla birlikte ebeveynler daha önce yaşamadıkları deneyimlerle karşı karşıya kalmaktadırlar. Okul öncesi eğitim çoğu ebeveynin çocuklarının sorumluluklarını ilk defa aile üyesi olmayan yabancı biriyle paylaştıkları zamandır (Gullo ve Hughes, 2011). Bir araştırmaya göre, çocukların okul öncesi eğitime başlamaları ebeveynleri endişelendirebilmekte ve ebeveynlerde karmaşık duygulara neden olabilmektedir (McClelland, 1995). $\mathrm{Bu}$ nedenle ebeveynlerin okullarla ve öğretmenlerle olan iletişimi, okula geldikleri zaman kendilerini iyi hissedecekleri bir ortam sağlanması önemlidir. Bu olumsuzluklara rağmen velilerin okul öncesi eğitimin zorunlu olmasını istedikleri ortaya koyulmuştur (Sak, Şahin-Sak, Öneren-Şendil ve Taşkın, 2020). Yapılan araştırmada, velilerin zorunlu okul öncesi eğitimin olumlu yönü olarak sosyalleşmeyi desteklediği, tüm gelişim alanlarını desteklediği, okula ve hayata uyumu kolaylaştırdığı, bireyler arasındaki farkları azalttı̆̆ 1 ve çocuğun özgüvenini desteklediği görüşüne sahip oldukları görülmüştür. Ancak çocukların ailelerinden uzak kalması ve ortaya çıkan ekonomik külfet ise veliler tarafından okul öncesi eğitimin olumsuz yönleri olarak belirtilmiştir (Sak vd., 2020). Ancak ortaya çıkan bu ekonomik külfet okul öncesi eğitim kurumları tarafından çocuğun bireysel ihtiyaçları için kullanılarak yapılan eğitime katkısının olduğu düşünülmektedir (Bilgiç, 2019).

Bazı ebeveynler çocuklarını akademik geleceklerinden endişe etmeleri nedeniyle çocuklarını okul öncesi eğitim kurumlarına gönderirken bazıları ise akademik başarıdan ziyade çocukların kendi özgüvenlerini oluşturmaları için göndermektedir (Brannon, 2005). Ceylan (2019) ebeveynlerin okul öncesi kurumlarını tercih sebeplerini, beklentilerini ve memnuniyetlerini araştırmıştır. Araştırmanın sonuçlarına göre ebeveynlerin çocuklarının mutlu olması, sosyalleşmesi ve daha iyi bir eğitim alması için okul öncesi eğitim kurumlarını tercih ettikleri ortaya çıkmışır. Kurumun ebeveynlerin evine yakınlığı ve güvenirliği, kurumun talep ettiği ücret ve kurum hakkında tavsiyeler velilerin okul öncesi kurum tercihlerinde rol oynamıştır. Ayrıca, ebeveynler öğretmenin ilgi ve yaklaşımı ile kurumdaki eğitim ve sosyal faaliyetlerin çeşitliliğinden memnun olmuşlardır. Ancak, ebeveynlerin daha bireysel eğitim, kurum ortamının ev ortamına benzemesi, daha fazla oyun ve hareketli aktivitelerin olması 
ebeveynlerin istekleri arasında ortaya çıkmıştır. Benzer bir çalışmada ise velilerin çocuklarını gönderecekleri okul öncesi kurum tercihlerinde kurumun güvenirliği, eğitim kalitesi, öğretmenlerin tecrübesi, okulun fiziki koşulları, yakınlığı, sınıftaki çocuk sayısı ve okul hakkında tavsiyelerin rol oynadığı belirlenmiştir (Topaç, Yaman, Ogurlu ve İlgar, 2012).

Ebeveynlerin çocuklarını okul öncesi eğitim kurumlarına gönderme nedenleri hakkında çeşitli sonuçların ortaya çıktığı araştırmalar mevcuttur. Graue (1993)'ün çalışmasına göre ebeveynler çocukların sosyal gelişimi ve akademik başarısı için okul öncesi eğitim kurumlarına başvurmaktadırlar. Araştırmada ortaya çıkan sonuçlara göre bazı ebeveynler çocukların gelişimlerini destekleyecek ortamı sağlayamayacaklarından endişe etmeleri üzerine çocuklarını bu kurumlara göndermişlerdir. Özyürek ve Ceylan (2014)'e göre, veliler çocuklarının sosyal becerilerinin geliştirilmesi için okul öncesi öğretmenlerden beklentileri olup, öğretmenlerin hem çocukların sosyal becerilerini desteklemek için çocuklara örnek olması gerekip, aynı zamanda da velilere bu konuda rehberlik etmesini beklemektedirler. Veliler çocuklarını akademik kaygılarla okul öncesi eğitim kurumlarına gönderebilmektedir. Bununla beraber, Wildenger ve McIntrye (2011) velilerin sadece çocuklarının okul öncesi dönemiyle ilgili değil, okul öncesi sonrasında ilköğretime geçişleriyle ilgili de endişe taşıdıklarını belirtmişlerdir. Bu nedenle veliler okul öncesi eğitimi aynı zamanda ilköğretime geçiş için hazırlık olarak görebilmektedirler.

Velilerin okul öncesi eğitim kurumları hakkında görüşlerinin birisi ise oryantasyon yetersizliğidir. Restall ve Borton (2009) dönem başlarında velilere yapılacak okul öncesi eğitim kurumu, sistemin işleyişi ve çevresiyle ilgili bilgilendirmelerin gerekli olduğunu, ebeveynler ile okul arasındaki iletişimin sağlıklı bir şekilde başlaması gerektiğini ve ebeveynlerin okul ile ilgili kararlardan haberdar edilmelerinin önemli olduğunu belirtmişlerdir. Bağçeli Kahraman (2018) çocukların okul öncesi eğitime başlarken yaşadıkları uyum sürecini incelediği çalışmada, okul başlangıcında anne ve babaların çocuklarını okula bırakarak bir veya iki gün okulda olduğu süre içerisinde beklediğini orta koymuştur. Bunun yanı sıra anneler, çocuklarının ilk günlerini okulda gözlemlediklerini vurgulamışlardır. Ancak, annelerin sadece \%57,7'sinin bu süreçte öğretmenden materyal, not, fotoğraf gibi geri dönütler alabildiklerini ifade etmişlerdir. Ailelerin süreç hakkında bilgilendirilmesi ve sürece dâhil edilmesi önemlidir. Nitekim okul öncesi eğitim başlangıcında olan çocukların okula uyumlarının anne baba tutumları, anne babaların empatik becerileri ile annelerin özyeterlik algısı gibi değişkenlerden etkilenebileceği vurgulanmaktadır (Başaran, Gökmen ve Akdağ, 2014). Bahçıvan, Kalay ve Bay (2018) bu süreçte oluşan okul aile işbirliğine yönelik velilerin beklentilerini araştırmışlardır. Araştırmada aileler öğretmenlerden çocukları hakkında daha fazla bilgi almak istedikleri, daha çok sosyal etkinliklerin yapılmasını bekledikleri bulgularına ulaşılmıştır. $\mathrm{Bu}$ sonuçlar istenen düzeyde okul aile işbirliğinin sağlanması açısından oldukça önemlidir.

Çocukların okuldaki güvenliği de veliler tarafından ortaya konan konular arasındadır. Jones (2006) çocuğunu okul öncesi eğitim kurumlarına gönderen ebeveynlerin \%31'i çocukları okuldayken onların güvenliği hakkında endişe taşıdıklarını belirtmiştir. $\mathrm{Bu}$ endişelerin nedenleri arasında ise zorbalık gelmektedir. Humphrey ve Crisp (2008) ebeveynlerin çocuklarının okul öncesi eğitim kurumlarında zorbalığa maruz kalmalarından endişe ettiklerini belirtmişlerdir. Ebeveynlerin bu endişeleri genellikle çocuklarının okulda yaşadıklarını anlatmasıyla oluşmaktadır. Okulda şiddet gören çocukların bazılarında alt ıslatma, sindirim problemi gibi sorunlar ortaya çıkabilmekte, bunlar da ebeveynlerde endişenin artmasına neden olabilmektedir.

\section{Yöntem}

\section{Araştırma Modeli}

$\mathrm{Bu}$ araştırma nitel özellikte olup bir durum çalışması olarak tasarlanmıştır. Araştırmada okul öncesi eğitim kurumlarına çocuklarını gönderen ailelerin okul öncesi eğitim hakkında düşünceleri, beklentileri ve sorunları araştırılmıştır. Bu bağlamda velilerle görüşmeler yapılarak şu sorulara cevap aranmıştır:

1. Velilere göre okul öncesi eğitim nedir? 
2. Velilerin çocuklarını okul öncesi eğitim kurumlarına gönderme nedenleri nelerdir?

3. Veliler okul öncesi eğitimde yürütülen hangi uygulamalardan memnundur?

4. Velilerin okul öncesi eğitime yönelik istek ve önerileri nelerdir?

\section{Çalışma Grubu}

Araştırmaya çocuklarını Kırşehir il merkezinde devlete bağlı herhangi bir okul öncesi eğitim kurumuna gönderen 11 gönüllü ebeveyn katılmıştır. Tablo 1 incelendiğinde görüleceği üzere katılımcıların cinsiyeti incelendiğinde, katılımcılar 7'si kadın (\%63) ve 4'ü erkek (\%37) velilerden oluşmaktadır.

Tablo 1

Araștırmaya katılan velilerin demografik özellikleri

\begin{tabular}{llc}
\hline Cinsiyet & $\boldsymbol{n}$ & $\boldsymbol{\%}$ \\
$\quad$ Kadın & 7 & 63,6 \\
Erkek & 4 & 36,4 \\
Okul Türü & & 54,5 \\
$\quad$ Bağımsı anaokulu & 6 & 45,5 \\
$\quad$ İlkokula bağlı anasınıfı & 5 & \\
Velilerin yaşı & $32,15 \pm 5,56(\min 26, \max 41)$ \\
\hline
\end{tabular}

Velilerin yaşları ise 26-41 arasında değişmekte olup ortalaması 32,15'tir. Velilerin 6's1 çocuğunu bağımsız anaokuluna $(\% 54,5)$ gönderirken 5 velinin çocuğu ilkokula bağlı anasınıfına $(\% 45,5)$ devam etmiştir.

\section{Verilerin Toplanması ve Analizi}

Araştırmada kullanılmak üzere veri toplama süreci 2019 Mayıs-Kasım ayları arasında gerçekleştirilmiştir. Katılıma gönüllü olan velilere araştırmanın amacı açıklanmış ve onayları alındıktan sonra araştırmaya dâhil edilmiştir. Araştırma sorularına cevap aramak amacıyla velilerle yar1 yapılandırılmış görüşmeler yapılmıştır. Görüşmeler 15 sorudan oluşmuş, veri kayb1 olmaması amacıyla ses kayıt cihazı ile kayıt altına alınmıştır. Daha sonra veriler yazıya aktarılarak MAXQDA programı üzerinde analiz edilmiştir. Velilerin isimleri analiz sürecinde V1, V2... şeklinde değiştirilmiştir.

Verileri analiz etmek amacıyla Lincoln ve Guba (1985) tarafından öngörülen kodlama süreci gerçekleştirilmiştir. Öncelikle velilere sorulan her soruya yönelik temel bir kod tablosu oluşturulmuş, daha sonra ortaya çıkan yeni kodlar ise bu kod tablosuna ilave edilmiştir. Analiz sürecinin devamında oluşan kod tablosunda bazı kodlar arası ilişki olduğu için bir araya getirilirken, bazı kodlar ise geliştirilerek ayrılmıştır.

Verilerin analiz sürecinin geçerliliğinin sağlanması amacıyla bazı durumlarda araştırmaya katılan velilerle görüşülerek söylediklerinin ne manaya geldiğini açıklamaları istenmiştir. Ayrıca, verilerin bir kısmı daha önce nitel araştırma analiz süreci gerçekleştirmiş ikinci bir kodlayıcı tarafından kodlanmıştır. Kodlayıcılar arası uyum katsayısı 0,94 olarak belirlenmiştir. Bu uyum katsayısının ise yeterli düzeyde olduğu görülmüştür (Miles ve Huberman, 1994).

\section{Araştırma Etiği}

Araştırmada kullanılmak üzere veri toplama süreci 2019 Mayıs-Kasım ayları arasında gerçekleştirilmiştir. Bu nedenle araştırmadan önce elde edilen etik kurul onayı bulunmamaktadır. Ancak, araştırma sürecinde bilimsel araştırma süreçlerinde dikkat edilmesi gereken hususlar göz önünde bulundurulmuştur. Katılıma gönüllü olan velilere araştırmanın amacı açıklanmış ve onayları 
alındıktan sonra araştırmaya dâhil edilmiştir. Elde edilen veriler bilimsel amaçla kullanılmak üzere kullanılmış, herhangi bir kişi veya kurumla paylaşılmamıştır.

\section{Bulgular}

$\mathrm{Bu}$ bölümde araştırmadan elde edilen verilerin analizi sonucunda oluşan bulgular yer almaktadır. Bulgular araştırma problemlerine cevap sağlayacak şekilde tablo haline getirilerek aşağıda sunulmuştur.

Velilere okul öncesi eğitimin onlar için ne anlam ifade ettiği sorulmuştur. Analiz süreci sonunda oluşan sonuçlar aşağıda yer alan Tablo 2'de sunulmuştur. Sonuçlar incelendiğinde veliler okul öncesini tanımlarken gelişim, beceri, uyum ve hazır bulunuşluk kavramlarına vurgu yapmışlardır. Veliler okul öncesi eğitimi tanımlarken bu kavramların desteklenmesi, öğrenilmesi ve kazanılmasını içeren süreç olduğunu vurgulamışlardır.

Tablo 2

Okul Öncesi Ĕ̈itimin Velilere Göre Tanımlanması

\begin{tabular}{lll}
\hline Kategori & $\%$ & \\
\hline Gelişim & 33,3 & fiziksel, duygusal, dil, zihinsel, ahlak, sosyal \\
Beceri & 30,0 & özgüven, yazma, konuşma, öğrenme \\
Uyum & 26,6 & sosyalleşme, çevreye uyum, akran etkileşimi \\
Hazır Bulunuşluk & 10,1 & ilkokula hazırlık \\
\hline
\end{tabular}

Velilerin okul öncesi eğitimi tanımlarken kullandıkları ifadelerin örnek alıntılarının bir tanesi şu şekildedir: "Okul öncesi eğitim çocukların zorunlu eğitim sürecinden önce fiziksel zihinsel ve duygusal yönden kendilerini fark edebildikleri ve bu yönde sosyal yönden gelişiminin sağlandiğg ve çocukların kendi becerilerini fark edebildikleri eğitim zamanıdır...[V1]”. Bu alıntı ve yukarıda yer alan tabloda görüleceği üzere veliler çocukların gelişimi kavramına okul öncesi eğitimin tanımında yer verirken fiziksel, duygusal, dil, zihinsel, sosyal ve ahlaki gelişimlerinden bahsetmişlerdir. Veliler beceri olarak çocukların özgüven, yazma, konuşma ve öğrenme becerilerini okul öncesi eğitimi tanımına dahil etmişlerdir. Ayrıca, okul öncesi eğitiminin tanımında uyum kavramı altında sosyalleşme, çevreye uyum ve akran etkileşimine yer vermişlerdir. Ayrıca, "Çocuğu ilkokula hazırlatır...[V5]" ifadesinden görülebileceği üzere, veliler okul öncesi eğitimin tanımında hazır bulunuşluk kavramı altında ilkokula hazırlığı vurgulamışlardır.

Tablo 3

Velilerin Çocuklarını Okul Öncesi Eğitim Kurumuna Gönderme Nedenleri

\begin{tabular}{lll}
\hline Kategori & $\%$ & \\
\hline Beceri Kazanımı & 44,0 & paylaşma, özgüven, yazma, araştırma \\
Sosyal Hayat & 28,0 & oyun oynama, akran etkileşimi, uyum \\
Gelişimi Destekleme & 16,0 & fiziksel, duygusal, zihinsel, ahlak \\
İlkokula Hazırlık & 12,0 & ilkokula geçiş \\
\hline
\end{tabular}

Velilere çocuklarını okul öncesi eğitim kurumlarına gönderme nedenleri sorulduğunda ise Tablo 3'te yer alan kategoriler oluşmuştur. Çocukların beceri kazanımı velilerin en çok vurguladığ 1 neden olmuştur. Farklı tür becerileri kazanmalarına örnek olarak V1 "Oyun oynama ve arkadaşlık ihtiyaçları gidermek, kişisel becerilerini ve ilgi alanlarını ortaya çıkarmak, kişisel bakım becerilerini kazandırmak, zorunlu eğitime alışmasını sağlamak için anaokuluna gönderiyoruz..." ifadelerini kullanmıştır. Paylaşma, özgüven gibi sosyal becerilerin yanı sıra yazma ve araştırma gibi bilişsel becerilerin çocuklar tarafından kazanılması velilerin çocuklarını okul öncesi eğitim kurumlarına göndermelerinde başlıca nedenler arasında yer almıştır. Çocukların beceri kazanımına ek olarak sosyal yönlerinin desteklenmesi, gelişimlerinin desteklenmesi ve bu sayede ilkokula hazırlanmaları velilerin çocuklarını okul öncesi eğitim kurumlarına göndermelerindeki diğer nedenler olmuştur. Bu nedenlere örnek olarak "Akranlartyla vakit geçirip, onlarla birlikte olmayl, mücadeleyi öğrensin, paylaşmayı ögrensin diye gönderiyoruz...[V10]" ve "Daha dikkatli bir şekilde eğiteme ilkokula hazır olması 
için...[V5]" ifadeleri velilerin çocuklarını okul öncesi eğitim kurumlarına gönderme nedenlerini özetlemektedir. Sonuç olarak veliler çocuklarını okul öncesi eğitim kurumlarına gönderirken onların beceri kazanımını, sosyal olarak etkileşimde olmalarını, gelişimlerinin desteklenmesi ve ilkokula daha hazır hale gelmelerini hedeflemektedir.

Velilerin okul öncesi eğitim kurumlarında yapılan uygulamalardan memnuniyet durumları incelendiğinde bazı olumlu ve olumsuz yönleri vurguladıkları görülmüştür. Olumlu yönler arasında sinema-tiyatro gibi faaliyetler, akranlarıyla oyun oynama, el becerilerini destekleyici etkinlikler, sorumluluk üzerine yapılan aktiviteler, çocukların eğlenerek öğrenmesi ön plana çıkmıştır. Veliler olumlu yönlerden bahsederken yapılan uygulama türlerinden duydukları memnuniyeti şu şekilde ifade etmişlerdir: "Yapılan serbest zaman etkinlikleri ile çocuklar fazla enerjilerini atıp eğleniyorlar... Matematik etkinliği olsun fen ve doğa etkinlikleri olsun bu tür etkinliklerde eğlenerek ögrenmeleri, yaratıcı oyunlar oynamaları hoşuma gidiyor...[V2]", "Birçok ögrrencinin zorlanırken bir yandan zevk alarak bir şeyler öğrenmesini sevinçle izliyorum. Okulda yaratıcı oyunlar oynuyorlar, yedikleri meyve ve sebzelerin kendilerine ne kadar yararlı olduğunu ögreniyorlar...[V9]”.

Velilerin memnuniyet durumları incelendiğinde ortaya çıkan olumsuz yönlere bakıldığg zaman ise, veliler maddi külfet gerektiren bazı aktiviteler olması, Türk kültürüne ait olmayan bazı kavramlara ve medya içeriklerine yer verilmesi ile bazı katı kurallar olduğunu belirtmişlerdir. Okul öncesi eğitimde yapılan bazı uygulamaların velilere maddi külfet oluşturmasından veliler şu şekilde bahsetmişlerdir: "Bence uygulamanın yaşa uygun olması ve veliye maddi sıkıntı vermeyecek olması gerekmektedir. Mali külfet getiren etkinlik ve uygulamalara karşıyım. Örneğin etkinliklere katılım için çocuğun bir daha kullanamayacağı pahalı elbiseler almaya zorlanması gibi...[V6]". Bunun yanı sıra, veliler okul öncesi eğitim uygulamaları esnasında çocukların gelişim özellikleri ve kültürlerine ait olmadan medya içeriklerine maruz kalmalarını ise olumsuz bir yön olarak belirtmişlerdir. "Yabancı müzikler veya yaşlarına uygun olmayan tarzda pop müzik eşliğinde olmasını sevmiyorum... [V11], Amaç kendi kültürünü yasayan bireyler yetiştirmek için çaba sarf etmek yerine ögrretmenlerin yabancı müzikler eşliğinde çocukların dans ettirmemesi gerekir...[V7]"

Tablo 4

Velilerin Okul Öncesi Eğitime Yönelik İstek ve Önerileri

\begin{tabular}{lll}
\hline Kategori & $\%$ & \\
\hline Öğretmenden Beklenti & 42,3 & $\begin{array}{l}\text { Sabırlı, bireysel özellikleri fark eden, hoşgörülü, sınıf içi otorite } \\
\text { sağlayan }\end{array}$ \\
Eğitim Ortamından Beklenti & 30,7 & Materyal, çocuk merkezli eğitim, aktif katılım \\
Maddi Konular & 15,3 & Maddi külfet, devlet yardımı \\
Diğer Öğrencilerden Beklenti & 11,7 & Temizlik, tuvalet, kurallara uyma \\
\hline
\end{tabular}

Velilerin okul öncesi eğitime yönelik istek ve önerileri Tablo 4'te sunulmuştur. Tablo incelendiğinde ise öğretmenden beklentiler, eğitim ortamından beklentiler, maddi konular ve diğer beklentiler olarak ön plana çıkmıştır. Veliler öğretmenlerin sabırlı, çocukların bireysel özelliklerinin farkında, sınıf içi otoritesini sağlayabilen ve hoşgörülü olmalarını beklemektedir. Ayrıca, sınıflarda yeterli malzeme ve materyal bulunması, çocukların aktif katıldığı ve bireysel özelliklerini sergileyebildikleri aktiviteler veliler tarafindan talep edilmektedir. "Okul öncesi eğitiminin zorunlu olması, sinıflarda yeterli materyal olması, ailelere fazla maddi külfet getirmemesi... [V6]" ifadesinden görüleceği üzere materyal ve maddi konularda velilerin beklentileri bulunmaktadır. Buna ek olarak V1 “...devletin ilkokullara kitap verdiği gibi okulöncesi setlerini de devlet belirleyip dağıtabilir, çünkü bunların her etkinliği maddi külfet getiriyor, bu da aileleri bıktırıyor..." ifadesi ise özellikle sınıf içi ve sınıf dışı faaliyetlerinin getirdiği maddi külfetin ortadan kaldırılmasının veliler tarafından beklenen bir durum olarak ortaya çıkmıştır.

\section{Sonuç, Tartışma ve Öneriler}

$\mathrm{Bu}$ araştırmada okul öncesi eğitim kurumlarına çocuklarını gönderen velilerin okul öncesi eğitim hakkında görüşleri ve kurum tercihleri incelenmiştir. Ayrıca, velilerin görüşlerine göre okul 
öncesi eğitimin olumlu ve olumsuz yönleri ile okul öncesi eğitime yönelik istek ve önerileri araştırılmıştır.

Araştırma bulgularına göre veliler okul öncesi eğitimi tanımlarken fiziksel, duygusal, dil zihinsel, ahlak ve sosyal gelişimlerine; yazma, konuşma, öğrenme gibi becerilere; çocukların sosyalleşmesi, çevreye uyum ve akran etkileşimi gibi uyum özelliklerine ve ilkokula hazırlık ile formal eğitime hazır bulunuşluklarına atıfta bulunmuşlardır. Nitekim veliler çocuklarını okul öncesi eğitim kurumlarına gönderme nedenlerinden bahsederken de okul öncesi eğitimi tanımlamakta kullandıkları kavramları vurgulamışlardır. Velilerin çocuklarını okul öncesi eğitim kurumlarına gönderme nedenleri olarak: çocukların yazma, araştırma, paylaşma gibi becerilerinin desteklenmesi; akran etkileşimi, oyun ve uyum gibi sosyal yaşantılarının zenginleştirilmesi; fiziksel, duygusal, zihinsel ve ahlak gibi gelişim alanlarının desteklenmesi; ilkokula geçiş sürecinde çocuğun daha hazırlıklı olması için ilkokula hazırlık hususları belirlenmiştir. Veliler çocuklarını okul öncesi eğitim kurumlarına gönderirken akademik kaygılar taşıyabilmekte veya çocukların özgüven gibi sosyal alanlarda faydalanması düşüncesinde olabilmektedirler (Brannon, 2005; Graue, 1993). Veliler çocukların okul öncesi dönemde ilkokula hazırlık yapılması gerektiğini düşünerek okul öncesi eğitim kurumlarını tercih edebilmektedirler (Wildinger ve McIntrye, 2011). Bu çalışmada da görüldüğü üzere veliler ilkokula geçiş, yazma becerileri gibi akademik başarıya yönelik sebeplerden bahsederken, aynı zamanda çocukların sosyal yaşantılarının desteklenmesi, oyun ve uyum becerileri gibi akademik başarıyla doğrudan ilişkisi olmayan hususları da vurgulamışlardır. Ceylan (2019) çocukların sosyalleşmesi ve daha iyi bir eğitim almaları için velilerin okul öncesi eğitim kurumlarını tercih ettiğini belirtirken akademik başarı ile birlikte okul öncesi eğitimin sosyal boyutunu da belirtmiştir.

Araştırma sonuçlarına göre, velilerin okul öncesi eğitim kurumlarında yapılan uygulamalardan memnuniyet durumları incelendiğinde, veliler çeşitli uygulamalar yapılmasını, akran etkileşimini ve çeşitli becerilerinin oyunlarla desteklenmesini vurgulamışlardır. Okul öncesi eğitimin olumsuz yönleri incelendiğinde ise ortaya çıkan maddi külfet ve çocukların kültürlerine yabancı olduğu düşünülen medya içeriklerine maruz kalmaları veliler tarafindan belirtilmiştir. Literatürde yer alan benzer çalışmalarda, okul öncesi eğitimin sosyalleşme ve gelişim alanlarını desteklemesi ile çocukların özgüvenini artırmaya yönelik süreçler içermesi olumlu yön olarak belirtilmiştir (Sak vd., 2020). Okul öncesi eğitimin veliler için oluşturduğu maddi yük de olumsuz yön olarak vurgulanmıştır (Bilgiç, 2019; Sak vd., 2020). Bu nedenle veliler okul öncesi kurum tercihlerinde maddi konuları da göz önüne almaktadırlar (Ceylan, 2019). Ancak, olumlu ve olumsuz yönler veliler tarafindan düşünüldüğünde, okul öncesi eğitimin zorunlu olması çocukların okul öncesi eğitime katılması veliler tarafindan önerilmektedir (Sak vd., 2020). Veliler tarafindan olumsuz olarak görülen bir diğer konu da okul öncesi eğitimde kullanılan kültür ögelerinin ev ile olan farklılığı olmuştur. Bu çalışmada veliler okul öncesi eğitimde kullanılan medya ögelerinin çocukların yaşadıkları kültürle olan uyumsuzluğunu belirtirken, konuyla ilgili diğer çalışmalarda ise ebeveynler kurum ortamı ile ev ortamı arasında ortak noktalar olması gerektiğini vurgulamışlardır (Ceylan, 2019). Okul öncesi eğitimin kültürel olarak çocuğa uygun olması önemlidir (Copple ve Bredekamp, 2009). Çocukların kültürlerine ait değerler, beklentiler, davranış ve dil özellikleri çocukların ev yaşamını şekillendirmektedir. Bu nedenle okul öncesi eğitimde yapılan uygulamaların çocukların kültürleriyle uyumlu, ilişkili ve o kültürlere saygılı olması önerilmektedir. Bu sayede çocuklar okul öncesi eğitim kurumlarına geldikleri zaman kendilerini daha rahat ve güvende hissedecek ve okul-ev arasındaki bağ daha güçlü olacaktır.

Velilerin okul öncesi eğitime yönelik istek ve önerileri incelendiğinde veliler öğretmenlerden otoriter, hoşgörülü ve bireysel özelliklerin farkında olmalarını; eğitim ortamının materyal yönünden zengin, aktif katılımın sağlandığı ve çocuk merkezli olmasını; maddi külfet konusunda devlet yardımını, diğer öğrenci ve velilerin ise temizlik ve okul kurallarına uymalarını istemektedirler. Öğretmenlerin çocuklara yaklaşımı ve okulun fiziki koşulları velilerin okul tercihinde rol oynamaktadır (Topaç vd., 2012). Sollars (2020) velilerin öğretmenlerin çocuklara bakış açısı ve sergiledikleri tutum; kurum ve aile arasındaki ilişki ve iletişim; çocukların mutluluğu ve kişisel gelişimi; ve okul ortamının fiziksel koşullarını doğrudan kalite ile ilişkilendirdiklerini belirtmiştir. Bu nedenle veliler okul öncesi öğretmenlerinden beklentileri olmaktadır. Öğretmenlerin çocukların sosyal becerileri desteklemek için onlara karşı olan tutumlarının daha uygun olması ve öğretmenlerin aynı zamanda çocuklara örnek olması veliler tarafından beklenmektedir (Özyürek ve Ceylan, 2014). Veliler 
okul öncesi eğitimde daha güçlü bir iletişim beklentisinde olabilmekte, okulla ilgili faaliyetler hakkında söz hakkı olmasını talep edebilmektedir (Bahçıvan vd., 2018). Okullar ve yöneticiler tarafından velilere yönelik hatırlatıcı mesajlar ile doğrudan iletişim kurumlasının velilerin daha aktif olmasını ve çocukların okul öncesi eğitime katılımını artırdığı vurgulanmaktadır (Weixler vd, 2020).

Bu çalışmada okul öncesi eğitim kurumlarına çocuklarını gönderen ebeveynlerin düşünce ve beklentilerine odaklanılmıştır. Ancak, araştırmanın bazı sınırlılıkları mevcuttur. Bu sınırlılıkların belirtilmesi ve bunları aşmak için gelecek çalışmalara yönelik önerilerde bulunulması önemlidir. Öncelikle araştırmada tek veri kaynağ1 veli görüşleri olmuştur. Veri toplama sürecinde velilerin görüşlerini objektif bir biçimde yansıttıkları kabul edilmiştir. İleride yapılacak araştırmalarda veli görüşlerini daha geniş bir zaman aralığında birden fazla seferde toplamak, analiz sürecine dahil etmek için velilerden zaman zaman okul öncesi eğitim hakkında düşüncelerini not etmelerini istemek gibi farklı yöntemler kullanılabilir. Ayrıca, bu araştırmada sunulan bulgular az sayıda velinin görüşlerini içermektedir. Araştırmanın nitel özellikte olması nedeniyle de bu araştırmanın sonuçlarını diğer velilere genellemek mümkün değildir. Bu doğrultuda, geçerlik ve güvenirlik çalışması yapılarak hazırlanacak bir ölçme aracı ile büyük örneklem grubu üzerinden nicel veri elde edilerek genellenebilir sonuçlara ulaşılması önerilmektedir. Böylece, okul öncesi eğitimin önemli bir paydaşı olan aile üzerine yapılacak olan çalışmalar, aileler hakkında daha kapsamlı bilgi edinilmesine ve okul-aile işbirliği ve iletişimini güçlendirmeye 1şık tutacaktır. Özellikle ailelerdeki farklılıklar ve bunun okul öncesi eğitim bağlamında neticeleri üzerine çalışmalar yapılması, okul öncesi eğitimin tüm topluma hitap edebilmesi ve ulaşabilmesi açısından önemlidir. Bu nedenle, farklı kesimlerden daha fazla katılımcılara ulaşılarak yapılacak çalışmalar daha derinlemesine bilgiler sunabilecektir.

\section{Kaynaklar}

Bağçeli Kahraman, P. (2018). Okul öncesi dönem çocuklarının okula uyum sürecine ilişkin anaokulu öğretmenlerinin ve annelerinin görüşleri. Erken Çocukluk Çalışmaları Dergisi, 2(1), 3-20.

Bay, D. N., Bahçıvan, E. ve Kalay, B. (2018). Okul öncesinde okul aile işbirliğine yönelik ailelerin ve öğretmenlerin görüşleri. Uşak Üniversitesi Eğitim Araştırmaları Dergisi, 4(3), 58-82.

Başaran, S., Gökmen, B. ve Akdağ, B. (2014). Okul öncesi eğitimde okula uyum sürecinde öğretmenlerin karşılaştığı sorunlar ve çözüm önerileri. Uluslararası Türk Eğitim Bilimleri Dergisi, 2014(2), 197-223.

Bilgiç, A. (2019). Anaokulu aidatlarına ilişkin görüşler. Tezsiz Yüksek Lisans Projesi, Pamukkale Üniversitesi, Eğitim Bilimleri Enstitüsü, Denizli.

Brannon, D. (2005). Full- or half-day kindergarten: What parents pick- and why, Education Digest, 4, 57-62.

Bronfenbrenner, U. (1989). Ecological systems theory. Annals of Child Development, 6, 187-249.

Ceylan, R. (2019). Ebeveynlerin okul öncesi kurumu hakkındaki görüşleri: Tercih sebepleri, beklentileri ve memnuniyetleri. Elektronik Sosyal Bilimler Dergisi, 18(70), 497-517.

Copple, C. and Bredekamp, S. (2009). Developmentally appropriate practice in early childhood programs serving children from birth through age 8. Washington, DC: National Association for the Education of Young Children.

Graue, M. E. (1993) Expectations and ideas coming to school, Early Childhood Research Quarterly, $8,53-75$.

Gullo, D. F. and Hughes, K. (2011) Reclaiming kindergarten: Part II: Questions about policy, Early Childhood Education Journal, 38, 393-397. 
Humphrey, G. and Crisp, B. R. (2008) Bullying affects us too: Parental responses to bullying at kindergarten, Australian Journey of Early Childhood, 33, 1, 45-49.

Kuru Turaşl1, N. (2010). Okul öncesi eğitimin tanımı, kapsamı ve önemi. G. Haktanır (Ed.) Okul öncesi eğitime giriş (s.1-23) içinde. Ankara: Anı Yayıncılık.

Jones, J. M. (2006) Parent concern about children's safety at school on the rise. Gallup News Service, $21-25$.

Lincoln, Y. S. and Guba, E. G. (1985). Naturalistic inquiry. Sage.

McClelland, J. (1995). Sending children to kindergarten, Family Relations, 44, 177-183.

Miles, M. B. and Huberman, A. M. (1994). Qualitative data analysis (2nd ed.). Sage.

Milli Eğitim Bakanlığı. (2013). Okul Öncesi Eğitim Programı. Ankara: Talim Terbiye Kurulu Başkanlığı.

Özyürek, A. ve Ceylan, Ş. (2014). Okul öncesi çocuklarda sosyal becerilerin desteklenmesi konusunda öğretmen ve veli görüşlerinin belirlenmesi. Pamukkale Üniversitesi Eğitim Fakültesi Dergisi, $35(35), 99-114$.

Restall, G. and Borton, B. (2009) Parents' concerns about their children's development at school entry, Child: Care, Health and Development, 36, 2, 208-215.

Sak, R., Şahin-Sak, İ. T., Öneren-Şendil, Ç. ve Taşkın, N. (2020). Eğitim Paydaşlarının Okul Öncesi Eğitimin Zorunlu Olmasına İliş̧in Görüşleri. Yaşadıkça Eğitim, 34(1), 58-78.

Sollars, V. (2020). Defining quality in early childhood education: parents' perspectives. European Early Childhood Education Research Journal, 28(3), 319-331.

Topaç, N., Yaman, Y., Ogurlu, Ü. ve İlgar, L. (2012, September). Okul öncesi dönem çocuğu olan ailelerin okul öncesi eğitim kurumu seçerken göz önünde bulundurdukları ölçütlerin incelenmesi. In New Trends on Global Education Conference. North Cyprus (pp. 24-26).

Toran, M. (2012). Çocukluğun ve erken çocukluk eğitiminin tarihi ve kuramsal temelleri. N. Avc1 ve M. Toran (Ed.) Okul öncesi eğitime giriş (s.1-19) içinde. Ankara: Eğiten Kitap.

Türkiye İstatistik Kurumu. (2020). Öğretim Yılına Göre Okul Öncesinde Net Okullaşma Oranı, Okul, Öğrenci, Öğretmen ve Derslik Sayısı. http://www.tuik.gov.tr/PreTablo.do?alt_id=1018 adresinden 10.06.2020 tarihinde ulaşı1mıştır.

Vygotsky, L. S. (1978). Mind in Society: The Development of Higher Psychological Processes. Cambridge, Massachusetts: Harvard University Press.

Weixler, L., Valant, J., Bassok, D., Doromal, J. B., \& Gerry, A. (2020). Helping Parents Navigate the Early Childhood Education Enrollment Process: Experimental Evidence From New Orleans. Educational Evaluation and Policy Analysis, 42(3), 307-330.

Wildenger, L. K. and McIntyre, L. L. (2011) Family concerns and involvement during kindergarten transition, Journal of Child \& Family Studies, 20, 387-396. 


\section{Extended Abstract}

\section{Introduction}

Early childhood education is that covers the period from birth of the children to the beginning of elementary school; aims to improve children's motor, cognitive, social, emotional, and language development; and provides rich learning environment to the children (Kuru Turaşl1, 2010). Ministry of National Education (MoNE, 2013) defines aims of early childhood education in Turkey as; creating a common environment for children who have low socio-economic backgrond; supporting body, cognitive and emotional development and children's acquiring good habits; preparing children to elementary school; and supporting children for their properly speaking Turkish language.

Family is one of the most important environments in which children grow. According to Bronfenbronner (1989) family is the closest environment to the children. Besides, Vygotsky (1978) implies that children learns through social interactions. Therefore, family and the culture of children should be taken into account for considering early childhood education. Within this context, this study aimed to focus on parents' views regarding early childhood education. To this aim, the concept of early childhood education according to the parents, parents' reasons for sending their children to early childhood institutions, and parents' satisfactory and demands from early childhood education were investigated in this study.

\section{Method}

This study was designed as a qualitative case study. Parents' views about early childhood education, their demands and problems were investigated in this study. To this aim, answers to the research questions below was sought in the study.

1. What is early childhood education, according to the parents?

2. What are the reasons of parents for sending children to early childhood institutions?

3. What implementations of early childhood education are satisfying for parents?

4. What are parents' demands related to early childhood education?

11 parents participated to the study. 7 participants were female and 4 participants were male. Mean of parents' age was 32.15 with 5.56 standard deviation. Maximum age of parents were 41, and minimum age was 26.

Semi structured interviews with the parents were done to collect data. The interviews included 15 open ended questions and the interviews were audio recorded. Then, the recordings transcribed and analyzed. Lincoln and Guba's (1985) coding procedure was applied during the analysis. Besides, to reliability of the analysis, a second coder included in the analysis. Inter-rater reliability was calculated as 0.94, according to Miles and Huberman's (1994) formula.

\section{Findings}

This study focused on parents' views regarding early childhood education. Results of the analysis revealed that parents used concepts of development, skill, accomodation and school readiness. Parents defined early childhood education as a process that includes supporting, learning, and acquiring these concepts.

The study also investigated the reasons of parents sending their children to an early childhood instution. It was revealed that parents send their children for acquiring skills such as sharing, selfconfidence, problem solving; for supporting social life of children as peer interaction, playing games, and accommodation to the environment; for supporting development areas of children such as physical, emotional, cognitive, and morals; and for preparing children to the elementary education. 
Besides, the study showed that parents thought that early childhood education had some pros and cons. According to the parents, the pros were activities such as cinema and theather, playing game with peers, activities for children's acquiring some skills and learning some concepts. On the other hand, the cons were financial barriers and the difference between children's home and school culture.

Lastly, the study investigated demands of parents related to early childhood education. The parents had some demands regarding teachers, the educational context, financial issues, and other parents and children. The parents defined teachers as patient, aware of individual differences between children and had authority in the classroom. Besides, parents demanded rich materials and childcentered activities in the educational context. Government aid was another demand of parents for overcoming the financial obstacles. Moreover, parents asked other children and parents for following common rules in the early childhood institutions.

\section{Conclusion, Discussion and Recommendations}

In this study, the opinions of parents who send their children to pre-school education institutions about pre-school education and institution preferences were examined. In addition, according to the opinions of the parents, the positive and negative aspects of preschool education and their wishes and suggestions for preschool education were investigated.

According to the findings of the research, when parents define preschool education, their physical, emotional, language, mental, moral and social development; skills such as writing, speaking, learning; adaptation characteristics such as socialization of children, adaptation to the environment and peer interaction; and their readiness for primary school and formal education. As a matter of fact, while talking about the reasons for sending their children to preschool education institutions, they emphasized the concepts they used in defining preschool education. As the reasons for parents to send their children to pre-school education institutions: Supporting children's skills such as writing, researching, sharing; enriching their social lives such as peer interaction, play and adaptation; supporting developmental areas such as physical, emotional, mental and moral; In order for the child to be more prepared during the transition to primary school, the preparation issues for primary school have been determined. Parents may have academic concerns while sending their children to pre-school education institutions, or they may think that children benefit from social areas such as self-confidence (Brannon, 2005; Graue, 1993). Parents can choose preschool education institutions considering that children should be prepared for primary school in the pre-school period (Wildinger \& McIntrye, 2011). As can be seen in this study, while parents talked about the reasons for academic success such as transition to primary school and writing skills, they also emphasized issues that are not directly related to academic success, such as supporting children's social life, play and adaptation skills. Ceylan (2019) stated that parents prefer preschool education institutions so that children can socialize and receive a better education, and also stated the social dimension of preschool education along with academic success.

This study focused on the thoughts and expectations of parents who send their children to preschool education institutions. Studies on the family, an important stakeholder of pre-school education, will shed light on obtaining more comprehensive information about families and strengthening school-family cooperation and communication. It is important to work on differences in families and the consequences of this in the context of pre-school education, in order for preschool education to appeal to and reach the whole society. Therefore, studies that will be conducted by reaching more participants from different segments will be able to provide more in-depth information. 